\title{
Removing All Reasonable Cause of Discontent: NoteWORTHy Decisions OF THE Alberta COURT OF APPEAL IN ABORIGINAL Litigation
}

\author{
ROBERT NORMEY*
}

This article examines the past 100 years of Aboriginal litigation at the Alberta Court of Appeal. It begins by describing pre-Charter cases related to historical hunting rights. It then examines cases related to division of power issues before describing cases concerning religious freedom, freedom to associate, and equality rights. Afterwards, cases concerning post-Charter Aboriginal and Métis hunting rights are discussed. Finally, the concepts of honour of the Crown and fiduciary duty are considered.
Cet article examine 100 ans de litiges autochtones portés devant la Cour d'appel de l'Alberta. Outre des causes antérieures à la Charte relatives aux droits de chasse ancestraux des Autochtones, l'auteur se penche sur des causes associées à la la division des pouvoirs, à la liberté religieuse, à la liberté d'association et aux droits à l'égalité. Il traite ensuite de causes postérieures à la Charte portant sur les droits de chasse des Autochtones et des Métis. L'auteur conclut son article en traitant des concepts relatifs à l'honneur de la Couronne et à son obligation fiduciale.

\section{TABLE OF CONTENTS}

I. INTRODUCTION . . . . . . . . . . . . . . . . . . . . . . . . . 100

II. Historical Hunting CASES OF Note Rendered PRIOR

TO THE CONSTITUTION ACT, $1982 \ldots \ldots \ldots \ldots \ldots \ldots$. . . . . . . . . . 100

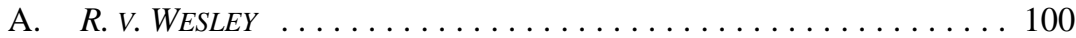

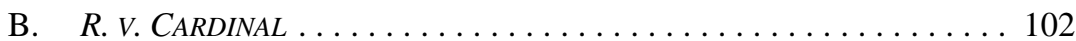

III. DIVISION OF POWERS AND APPLICATION

of Provincial LaW on Reserve . . . . . . . . . . . . . . . . . . . . . . . 103

A. RE STONY PLAIN INDIAN RESERVE NO. 135 DEVELOPMENT . . . . . . 103

B. WESTERN INDUSTRIAL CONTRACTORS LTD. V.

SARCEE DEVELOPMENTS LTD. . . . . . . . . . . . . . . . . . 103

IV. REligious FreEdom AND FREEdOM TO ASSOCIATE (PRE-CHARTER)

AND SECTION 15 EQUALITY RIGHTS (CHARTER) . . . . . . . . . . . . . . 104

A. R. V. GINGRICH . . . . . . . . . . . . . . . . . . . . . . . . . . 104

B. AugER V. THE WORKERS' COMPENSATION BOARD (ALTA.) . . . . . . . 104

V. LATER TREATy/NRTA Hunting AND FISHING CASES . . . . . . . . . . 105

A. R. V. HORSEMAN ....................... 105

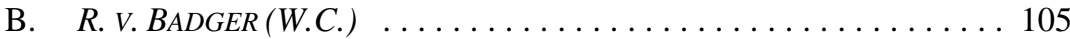

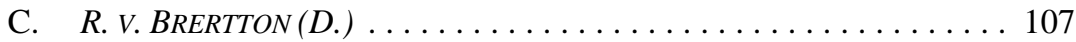

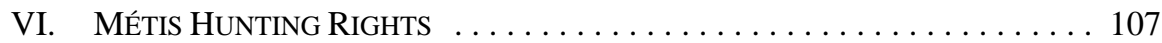

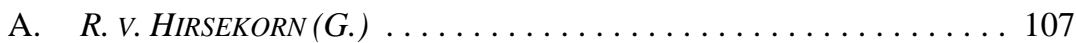

VII. TREATy OBLigations, HonOUR OF THE CROWN,

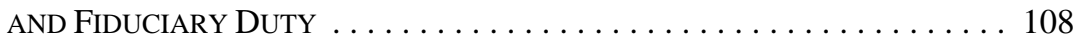

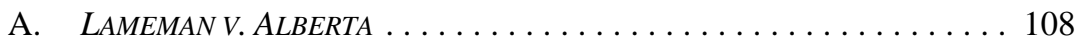

Barrister and Solicitor at Alberta Justice and Solicitor General. Mr Normey practices both constitutional and Aboriginal law, and has taught Constitutional Litigation and Jurisprudence at the University of Alberta. Mr Normey has appeared before the Court of Appeal and Supreme Court of Canada many times. 
"Let us face it, we are all here to stay"

- Chief Justice Lamer ${ }^{1}$

"We were given a diamond for Christmas instead of a lump of coal."

- Herb George Satsan²

\section{INTRODUCTION}

This brief survey of the Court of Appeal's decision-making in the field of Aboriginal law demonstrates that a diverse range of issues confronted Aboriginal peoples as they endeavoured to respond to the new reality of expansion and settlement by Euro-Canadians. The Crown asserted sovereignty over the lands making up this province but also entered into those "sacred agreements" or treaties upon which future development and prosperity has been and will continue to be based. Prior to the Constitution Act, 1982 and the entrenchment of section 35, which recognizes and affirms Aboriginal and treaty rights, the Court was presented with the difficulty of how properly to accord a measure of protection to treaty rights. The case of $R$. v. Wesley reveals one praiseworthy means of doing so. Subsequent decisions of the Court dealt with other significant matters and in doing so have greatly impacted the Crown-Aboriginal relationship. A selection of these follows.

\section{Historical Hunting Cases of Note Rendered PRIOR TO THE CONSTITUTION ACT, 1982}

\section{A. R. V. WESLEY}

In a superb series of radio dramas, the CKUA Radio Network some years ago featured great legal dramas of the first half of the twentieth century: Great Alberta Law Cases. ${ }^{3}$ The case from the 1920s that remains vividly in mind was the Nat Bell Liquors case, a matter handled with great skill by Chief Justice Harvie of the Supreme Court of Alberta (Appellate Division). ${ }^{4}$ The name of the program was Prohibition Blues and indeed, my quick survey of the Western Weekly Reports revealed a high number of cases dealing with illegal sales of liquor or licensing issues (liquor being available for medicinal purposes or cross-border sales).

Member of one of the First Nations responding to the ruling. See J Aubry, “'Major Victory' on Land Claims" The Montreal Gazette (12 December 1997) A1, cited in John Borrows, "Sovereignty's Alchemy: An Analysis of Degalmuukw v. British Columbia” (1999) 37:3 Osgoode Hall LJ 538 at 543, n 30 .

3 Marylu Walters, CKUA Radio Worth Fighting For (Edmonton: University of Alberta Press, 2002) ([i]n 1989 CKUA collaborated with the Alberta Law Foundation to co-produce 'Great Alberta Law Cases'” at 253).

$4 \quad R v$ Nat Bell Liquors Ltd (1921), 16 Alta LR 149 (SC (AD)). It was eventually appealed to the Privy Council: $R$ v Nat Bell Liquors Ltd, [1922] 2 AC 128 (PC). 
It was in the 1930s that the Alberta Court of Appeal was asked to engage with Indian hunting rights in a significant way. In R. v. Wesley, ${ }^{5}$ Justice McGillivray ${ }^{6}$ (Justices Clarke and Mitchell concurring), wrote a progressive and expansive judgment on the interplay of the numbered Indian treaties and the Natural Resources Transfer Agreement (NRTA), which had only recently come into force. ${ }^{7}$ Rather than reading the hunting rights in a limited context, confined to a technical treatment of paragraph 12 of the NRTA, he diligently examined a number of documents and the historical evolution of the Crown and First Nations relationship to come to a proper understanding of the treaty right to hunt, as modified by the NRTA.

The facts of the case are as follows: William Wesley, a Stoney Indian living on the Morley Reserve west of Calgary, was charged under The Game Act of Alberta for hunting for food within the lands covered by Treaty No. $7 .^{8}$ Wesley had hunted and killed a deer with antlers less than four inches and done so without a licence. The question was whether or not The Game Act applied, in which case he would be found guilty. ${ }^{9}$ He argued that he had a treaty right to hunt, as he was doing so on unoccupied Crown lands. The matter proceeded as a test case. The stark contrast between how the issues were considered and disposed of by the magistrate at trial and then by Justice McGillivray on appeal makes evident just how remarkable the latter's reasoning was for 1932.

The magistrate considered that both the hunting rights clause in Treaty No. 7 and paragraph 12 of the recently enacted NRTA, 1929 (forming part of the Constitution Act, 1930 $)^{10}$ should be read as making any "right" subject to all competent provincial game laws. ${ }^{11}$ He also prevented the defence from calling proposed evidence of how the Indians who were present at the 1877 signing of Treaty No. 7 would have understood the hunting rights clause, reasoning that the Treaty speaks for itself. ${ }^{12}$

Justice McGillivray moved well beyond such a narrow and ahistorical approach to treaty interpretation and adopted a stance that reveals a marked similarity to the approach that certain later members of the Court as well as the Supreme Court of Canada would come to emphasize some decades later. To arrive at a comprehensive understanding of the broader intentions of the Crown and various First Nations, he examined such documents as the Articles of Capitulation of Montreal of 1760, the Treaty of Paris of 1763 and the Royal

\footnotetext{
$R v$ Wesley (1932), 26 Alta LR 433, (SC (AD)) [Wesley].

Justice Alexander McGillivray came to Alberta in 1907, having graduated from Dalhousie Law School. He was admitted to the Northwest Territories Bar in 1907, before the Alberta courts were established. McGillivray was considered to be a brilliant barrister. He was known for his work as special Crown Prosecutor in the trial of Emilio Picarielle and Florence Lassandra who were convicted of the murder of a police officer. The shooting took place following his attempt to apprehend a bootlegger — the illicit sale and transportation of liquor again!) For a time in the 1920s, McGillivray served in the Alberta Legislature as Conservative leader. He was appointed as a Justice of the Supreme Court, Appellate Division in 1931 at the age of 47, making him one of the youngest appellate court justices in the country: see Brenda McCafferty, "Following in Father's Footsteps" (2004-2005) 13:2 Architypes 3.

The Alberta Natural Resources Act, 1930 SA, c 21, Schedule.

RSA 1922, ch 70.

Wesley, supra note 5 at 439-40.

(UK) 20 \&21, Geo V, c 26.

Wesley, supra note 5 at 438; Douglas Sanders, “The Queen’s Promises” in Louis A Knafla, ed, Law \& Justice in a New Land: Essays in Western Canadian Legal History (Toronto: Carswell, 1986) 101 at 105.
}

12 Ibid. 
Proclamation of $1763 .{ }^{13}$ The last document he placed particular significance upon, referring to it as sometimes "spoken of as the 'Charter of Indian Rights." " ${ }^{14}$ He also made innovative use of the Supreme Court and Privy Council St. Catherines Milling decisions of 1887 and 1888, and other decisions of the Privy Council. ${ }^{15}$ A variety of other documents, including those containing details of the treaty negotiations, were all placed in the service of a purposive approach to the meaning of the words in the treaty hunting and fishing rights clause and the hunting and fishing rights section of the NRTA. ${ }^{16}$

Justice McGillivray placed upon the language of the treaties, as modified by the NRTA, an expectation that the Crown's promises will be carried out "with the exactness which honour and good conscience dictate" and referred to equitable principles to be applied. ${ }^{17} \mathrm{He}$ concluded his judgment with a ringing pronouncement that the treaty-makers (and by implication the drafters of the NRTA) surely would not have contemplated a deprivation of "an unfettered right to hunt game of all kinds for food on unoccupied Crown land." ${ }^{8}$ The appeal was granted. Near the end of the judgment he expressed his satisfaction over the conclusion that “the Queen's promises” would still be fulfilled. ${ }^{19}$ He declared: "It is satisfactory to think that legislators have not so enacted but that the Indians may still be 'convinced of our justice and determined resolution to remove all reasonable cause of discontent.", 20

This article spends considerable time on Wesley because it is an exemplary and generous interpretation of the NRTA, at a time when such an approach would have been quite unusual. It sets a precedent for later cases, including Sikyea v. The Queen and Prince and Myron v. The Queen. ${ }^{21}$

\section{B. R. V. CARDINAL}

Justice Clement ${ }^{22}$ rendered this decision on the applicability of the The Wildlife Act to an Indian hunter who had made a sale of moose meat. ${ }^{23}$ Once again it was necessary to scrutinize paragraph 12 of the NRTA as it pertained to an Indian possessing a treaty right to hunt. Considerable reliance was placed upon the Wesley decision, as well as the Prince and Myron decision which had made use of the former. ${ }^{24}$

Wesley, supra note 5 at 444.

Ibid.

Wesley, ibid at 446; St Catharines Milling and Lumber Co v The Queen (1886), 13 SCR 577 [St Catherine's Milling]; St Catherine's Milling and Lumber Company v The Queen (1889), 14 AC 46 (PC). Wesley, ibid at 444-48.

Ibid at 449 .

Ibid at 450 .

Ibid at 451.

Ibid.

Sikyea v The Queen, [1964] SCR 642; Prince and Myron v The Queen, [1964] SCR 81 [Prince and Myron].

22 The Honourable Carlton Ward Clement was very active in both the law profession and the wider community, serving as President of the Edmonton Chamber of Commerce. In their book Lords of the Western Bench Louis Knafla and Richard Klumpenhouwer describe Justice Clement as one who combined scholarship with practicability and as authoring a number of significant judgments on the parameters of jurisdiction in the province and the circumstances in which an appeal court should interfere with trial decisions: Louis Knafla \& Richard Klumpenhouwer, Lords of the Western Bench: A Biographical History of the Supreme and District Courts of Alberta, 1876-1990 (Calgary: Legal Archives Society of Alberta 1997) at 28-29. 
Justice Clement interpreted the NRTA as possessing an overriding purpose of securing a supply of game for Indians with hunting rights. Thus there was a right and responsibility to enact proper conservation measures. He viewed the provincial prohibition on the sale of game as coming within the conservation objective. Hence it was applicable to the accused, who must be convicted as he extended his activities beyond hunting for food directly. ${ }^{25}$

\section{Division of PoWers And Application of Provincial LAW ON RESERVE}

\section{A. Re Stony Plain Indian Reserve No. 135 DeVelopment}

This was a significant case inasmuch that the reference required the Court to respond to a large number of detailed questions of great importance for First Nations wishing to initiate commercial developments on reserve lands. ${ }^{26}$ While sections 37 and 38 of the Indian Act set out the general ability of an Indian band to sell, convey, lease, or grant interests in the reserve land, ${ }^{27}$ in order for a reserve to fully utilize its lands it was important to clarify whether a surrender, together with a right of reversion to the band after a period of time, would amount to an absolute surrender or not. ${ }^{28}$ The Court of Appeal noted: "an absolute surrender followed by a disposition of the reserved land frees the land from the Indian burden.... [I]f the Band retains the reversion, the burden remains at least in so far as the reversionary interest is concerned."29

The answers given recognized that conditional surrenders would not cause the land in question to cease to be part of the reserve, thereby allowing provincial laws to apply under the division of powers. Rather, a conditional surrender allows a commercial development to proceed within lands making up the reserve, with the various benefits attached to such lands. $^{30}$

\section{B. WESTERN INDUSTRIAL CONTRACTORS LTD. V. SARCEE DEVELOPMENTS LTD.}

In this case another division of powers issue arose, namely whether a builder's lien, under the provincial Builder's Lien Act, could be filed against the leasehold interest of an Alberta company in lands within an Indian reserve following a conditional surrender of the particular portion of the reserve to the Crown by the Sarcee First Nation. ${ }^{31}$ It was held that provincial law was applicable in the circumstances, as the interest claimed was only in relation to that held by the company and was not against the beneficial or residual interest of the Indian band. ${ }^{32}$ This is another case contributing to our understanding of how commercial activity,

Ibid at 722-23.

Re Stony Plain Indian Reserve No. 135 Development (1981), 35 AR 412 (CA) [Stony Plain Indian Reserve].

RSC 1985, c I-5, ss 37-38.

Stony Plain Indian Reserve, supra note 27 at paras 31-32.

Ibid at para 38.

Ibid at para 63.

Western Industrial Contractors Ltd v Sarcee Developments Ltd (1979), 15 AR 309 at paras 14-16 (CA). Ibid at paras 59-60. 
in this case building construction, can take place with the protections afforded by provincial law, having no such comparable federal law being available.

\section{Religious Freedom AND FreEdom to AsSOCIATE (PRE-CHARTER ${ }^{33}$ ) AND SECTION 15 EQUALITY RIGHTS (CHARTER)}

\section{A. R. V. GINGRICH}

This is a unique case which needs to be better known. Members of the Blood First Nation requested the opportunity to invite a missionary onto the Blood Reserve to attend at their homes in order to minister to them. The Band Council refused to issue permits to him and they ultimately charged him with trespass. ${ }^{34}$ Chief Justice Ford, for the Court, in the course of his reasoning, emphasized that all Canadians, including those residing on reserves, possess basic rights that must be recognized in the absence of a clearly expressed treaty right that would conflict with the generally held rights. One of those rights is that of religious freedom. ${ }^{35}$ Reference was made to section 129 of the British North America Act, which made the previously enacted Rectories Act of 1851, permitting the free exercise of religion without discrimination, law in Canada. ${ }^{36}$ Chief Justice Ford dismissed the argument that the missionary could be trespassing in these circumstances, concluding that " $[\mathrm{t}]$ he right to preach and teach the gospel, as well as to hear it preached and taught, is recognized in a free society." 37

\section{B. Auger V. THE WORKERS' Compensation BoARd (ALTA.)}

This case concerned a challenge to the applicability of the regulation under the Alberta Workers' Compensation Act defining “industry" in a manner excluding an Indian or Indian Band on reserve as employer, on the basis that it discriminates against Indians. ${ }^{38}$ Whereas the chambers judge had found that the regulation did not violate section 15(1) of the Charter, the Alberta Court of Appeal chose to turn to section 1 of the Charter. Assuming that a prima facie breach had occurred, the Court found that the regulation constituted a reasonable limit. ${ }^{39}$ Evidence had been provided which established that exclusion of Indian or band employers on the reserve from compulsory coverage under the Workers' Compensation Act was necessary in order to assume and maintain the integrity of the accident fund. ${ }^{40}$ The Court needed to examine the interplay of section 89 of the Indian Act with the provincial regime. The Court agreed with the conclusion of the learned chambers judge: "To give employees of execution-proof employers a mandatory right to compensation would be unreasonable in my opinion, especially when any infringement of the employee's s. 15(1) right is impaired to a minimum because voluntary coverage is available." 41

\footnotetext{
33 Canadian Charter of Rights and Freedoms, Part I of the Constitution Act, 1982, being Schedule B to the Canada Act 1982 (UK), 1982, c 11 [Charter].

$R \vee$ Gingrich (1958), 29 WWR 471 at 472 (Alta CA).

Ibid at 474.

Ibid.

Ibid.

Auger v The Workers' Compensation Board (Alta) (1990), 111 AR 2 at para 1-3 (CA) [Auger (CA)]. Ibid at paras 7-8.

Ibid at para 10.

Auger v Alberta (Workers' Compensation Board) (1989), 61 DLR 4th 660 at 671 (QB), cited in Auger (CA), supra note 38 at para 12 .
} 


\section{LATER Treaty/NRTA HunTing AND Fishing CASES}

\section{A. R. V. HORSEMAN}

In this case, the Court needed to extend its analysis beyond Wesley and further consider the interplay of the Wildlife Act and the treaty right to hunt, and how it had been impacted by the NRTA. ${ }^{42}$ The accused hunter had shot and killed a grizzly bear in self-defence. However, he then proceeded to sell the meat for money to buy food. Justice Foisy for the Court held that the accused's right to hunt did not extend to the sale of meat, which is an activity beyond "hunting for food" and enters the domain of commerce. ${ }^{43}$ As part of his analysis, Justice Foisy interpreted the wording of paragraph 12 of the NRTA as an express repeal of the Treaty, and then a replacement of the right with the right set forth in the NRTA. ${ }^{44}$ This approach was generally accepted by the Supreme Court of Canada, which referred to what had transpired as a "merger and consolidation" of the hunting rights. ${ }^{45} \mathrm{~A}$ quid pro quo was said to have been created, with a subtraction of part of the treaty right but the extension of the right, particularly its geographical extent, being simultaneously provided. $^{46}$

\section{B. R. V. BADGER (W.C.)}

This case is one of the leading decisions by this Court and the Supreme Court of Canada on treaty rights in Canada. ${ }^{47}$ The appeal involved three separate Aboriginal hunters who were each found to have violated the Wildlife Act. Each claimed to be hunting on unoccupied Crown lands, being private lands that did not appear to them to be put to any particular use at the time of the hunt. Each member of the panel (Justices Lieberman, Kerans, and Conrad) provided different reasons for concluding that the hunting right did not afford a defence.

The decision of Justice Kerans is quite remarkable inasmuch as he subjects the "merger and consolidation" theory to critical scrutiny and uncovers serious flaws. ${ }^{48} \mathrm{He}$ also observed that replacing treaty rights with NRTA rights caused him considerable disquiet, as Aboriginal people whose rights were fairly significantly affected were not consulted in any way. ${ }^{49}$ Justice Kerans examined three recent Supreme Court cases in the rapidly expanding jurisprudence of the 1980s and concluded that it was not easy to reconcile the approaches adopted. ${ }^{50}$ He considered himself bound to follow Horseman but stated that the decision was deeply troubling. ${ }^{51}$ He opined that rather than intending to extinguish treaty rights and replace them with new rights under the NRTA, governments simply proposed to confer on the province the right to regulate hunting, but subject to the treaty rights as specified in the treaty

$R v$ Horseman (1987), 78 AR 351 at para 5 (CA).

Ibid at para 46.

Ibid at para 29.

$R v$ Horseman, [1990] 1 SCR 901 at 931-932 [Horseman].

Ibid at 933.

$R v$ Badger (WC) (1993), 135 AR 286 at paras 5-6 (CA).

Ibid at paras 23-24.

Ibid at para 23.

Ibid at paras 19-20.

Ibid at para 20. 
document. ${ }^{52}$ He declared: “I fear the notion of 'merger and consolidation' is the result of a patina applied by a later generation of judicial interpretation.”53

Justice Conrad considered that Horseman dealt with the right to hunt commercially on Crown lands, so was not binding on the separate issue of hunting on private lands. ${ }^{54}$ She examined phrases in both the Treaty and the NRTA to reach a conclusion as to what was intended for the locations where hunting could occur. She concluded that in transferring a given tract to a private owner, the lands were thereby "required or taken up" and so no longer "unoccupied" as that word is used in the NRTA. Accordingly the right to hunt did not extend to the lands in question. ${ }^{55}$

I note that I was not counsel at this level. However, I was assigned the matter as we responded to the appeal to the Supreme Court of Canada. I remember being persuaded of the necessity of revisiting the relationship between the Treaty and the NRTA as we prepared our factum. While we did not adopt any of the views of the justices in their entirety, we were certainly influenced by them in developing our approach, and decided that the NRTA modified the Treaty right, rather than extinguishing it and replacing it with a new right. We also made submissions about the quid pro quo involved in effecting the modification. It was undeniable that First Nations were not consulted about this modification, but of course this was an unfortunate reality of our historical development.

The Supreme Court concluded on this point that section 1 of the Constitution Act, 1930 (incorporating the NRTA) is undoubtedly binding but its existence has not deprived the Treaty itself of legal significance. ${ }^{56}$ The Court employed the concept of the honour of the Crown and emphasized that treaties are sacred, and concluded that only in the clearest of cases will it find that the treaty has been amended. ${ }^{57}$ The right to hunt was found to have been amended, but many of the concepts and an understanding of common intention under the Treaty still govern the analysis of the modified right. ${ }^{58}$ This case partially synthesizes the views of Justices Kerans and Conrad from the Court of Appeal.

An interesting aspect of the case is that one of the counsel for the appellant hunters was Tony Mandamin, now the Honourable Leonard S. Mandamin of the Federal Court of Canada. Justice Mandamin, an Anishnawbe member of the Wikwemikong Unceded Indian Reserve on Manitoulin Island, was previously a provincial court judge who "[p]resided in the Tsuu T'ina Court which involved a First Nation peacemaker justice initiative and in the Siksika Court at Siksika which also involved traditional aboriginal mediation." ${ }^{59}$ He and I established a good rapport, which allowed him to overlook the fact that I included in my materials a federal report (describing the NRTA), authored by Deputy Superintendent Duncan Campbell

Ibid at para 24.

Ibid at para 23.

Ibid at para 56.

Ibid at paras 83-84.

$R$ v Badger, [1996] 1 SCR 771 at para 47 [Badger].

Ibid.

Ibid at para 100 .

See “The Honourable Leonard S. Mandamin,” online: Federal Court <http://cas-ncr-nter03.cas-satj.gc. ca/portal/page/portal/fc_cf_en/mandamin>. 
Scott, who has a less-than stellar reputation in Aboriginal communities. ${ }^{60}$ Tony and I became friends after Badger, and I have followed his career with great interest.

\section{R. V. BRERTTON (D.)}

The Supreme Court in Badger ultimately interpreted the modified right to hunt as extending to lands not visibly in use and not incompatible with exercising the right ${ }^{61} R$. $v$. Brertton (D.) was an early and significant application of the new "Badger test" to a challenging set of facts. ${ }^{62}$ The definition of the "visible, incompatible use" test was affirmed by the Court to include "not what a particular hunter saw, but what signs of visible, incompatible use could be viewed from his vantage point if exercising due diligence."

As one of the counsel in the case, I had instructed that a large, detailed map be prepared. A large number of photos of the kill site on reclaimed land within an active mining area were also in evidence. I well remember the diligent work of the panel and counsel to understand in the most precise terms where the hunt took place in relation to mining activity and in relation to various "no trespassing” signs.

\section{MÉtis Hunting Rights}

\section{A. R. V. HIRSEKORN (G.)}

This matter arose out of the shooting of a mule deer near a community within the Cypress Hills. The accused was charged under the Wildlife Act with hunting wildlife during a closed season and being in possession of wildlife without a permit. ${ }^{63}$ His defence was that he possessed an Aboriginal right to hunt protected by section 35(2) of the Constitution Act, 1982. ${ }^{64}$ However, the evidence did not support the presence of Métis in the Cypress Hills prior to 1870, when a European or Euro-Canadian presence was established. ${ }^{65}$

This case involved an examination of Aboriginal rights from the prism of the test enunciated by the Supreme Court in R. v. Powley. ${ }^{66}$ This involved adopting a "'generous, liberal interpretation [of the constitutional provision],' and analyzing it in light of the interests it was meant to protect. This means reconciling the fact that aboriginals lived on the land in distinctive societies, with their own practices, traditions and cultures, with the sovereignty of the Crown." 67

Justice Paperny for the Court reviewed expert evidence extensively in her judgment before applying the Powley test to the facts. In reconciling the respective positions of the Métis community here and that of the Crown, she found it was necessary to apply a "pre-control"

A fascinating examination of Scott's career and cultural significance can be found in Mark Abley, Conversations with a Dead Man: The Legacy of Duncan Campbell Scott (Madeira Park: Douglas \& McIntyre, 2013).

Badger, supra note 56 at para 54.

(1999), 244 AR 355 (CA), aff'g (1998), 217 AR 224 (QB).

$R v$ Hirsekorn (G), 2013 ABCA 242, 556 AR 53 [Hirsekorn].

Ibid at para 2.

Ibid at para 105.

Ibid at para 4; $R$ v Powley, 2003 SCC 43, [2003] 2 SCR 207 [Powley].

Hirsekorn, ibid at para 47. 
test for the establishment of Métis rights, allowing the Court to identify practices predating the imposition of European laws and customs on the Métis people. ${ }^{68}$ It was necessary to determine if the trial judge had correctly reached the conclusion that the establishment of control occurred in 1884 with the arrival and continued presence of the North West Mounted Police. The Court found that evidence substantiated the trial judge's conclusion. ${ }^{69}$

The other key issue in assessing the claimed right was the question of which hunting

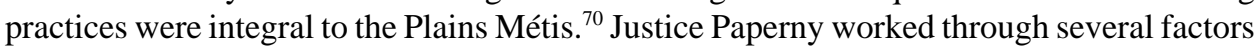
in her reasoning to conclude that the "place" that was integral to the Plains Métis did not encompass the Cypress Hills in the pre-control era. ${ }^{71}$ Whatever limited presence the Métis had was not sufficient to become part of a pattern making up an integral practice. ${ }^{72}$ Accordingly, the Court dismissed the appellant's claim. ${ }^{73}$

\section{TREATY OBLigations, HONOUR OF THE CROWN, AND FIDUCIARY DUTY}

\section{A. LAMEMan V. Alberta}

The Court in Lameman upheld the dismissal of an application by Alberta and Canada to strike certain portions of a Further Amended Statement of Claim of the Beaver Lake Cree Nation. ${ }^{74}$ A claim was made for damages for alleged breaches of obligations imposed on Alberta and Canada pursuant to Treaty No. 6. The First Nation claimed that the "cumulative effect of various government 'authorizations' of developments related to oil and gas, forestry, mining and other activities on the core lands" resulted in the deprivation of the right to hunt, trap, and fish. ${ }^{75}$ They claimed that the "core lands" where those that Alberta and Canada are obliged to manage in such a way as to enable the continuation of hunting, trapping, and fishing. ${ }^{76}$

This case, while dealing simply with an interlocutory motion, is germane to this whirlwind survey of Aboriginal law at the Court of Appeal because it highlights complex and crucial issues for First Nations and society as a whole as we look ahead over the coming decades. The issue of cumulative effects through major developments over time is novel and will require the weighing and balancing of a number of factors as part of the adjudicative process. The Alberta Court of Appeal, in rejecting the appeal and refusing to dismiss the claim, canvassed the distinct responsibilities that the Crown has under both the fiduciary duty and the honour of the Crown, and drew on the discussion of these vital legal concepts in the recent Supreme Court of Canada decision in Manitoba Metis Federation Inc. v. Canada (Attorney General). ${ }^{77}$

Ibid at para 70 .

Ibid at paras 97-98.

Ibid at paras 104-105.

Ibid at para 109.

Lameman v Alberta, 2013 ABCA 148, 553 AR 44 [Lameman].

Ibid at para 5.

Ibid at para 4

Ibid at paras 50, 52; Manitoba Metis Federation Inc v Canada (Attorney General), 2013 SCC 14, [2013] 1 SCR 623. 
With cases like Lameman as our guide, we can anticipate that the next 100 years of decision-making by the Court of Appeal will be as crucial to Alberta's development as the decisions of the first 100 years have been. 